\title{
Social Media Utilization in Generating Fast Response During Urban Flooding: A Case Study of Depok City
}

\author{
Muhammad Akram Mansyur ${ }^{1}$ \\ \{muhammadakram@staff.gunadarma.ac.id ${ }^{1}$ \} \\ University of Gunadarma, Jl. Margonda Raya No.100, Depok, Indonesia ${ }^{1}$
}

\begin{abstract}
Social media is a technology that has evolved very quickly in the past decade. not only its tremendous growth of users, but the scope of its purpose has expanded, for instance its use in a crisis situation as will be elaborated in this paper. This study is aiming to construct theoretical explanation about the utilization of social media by citizens and municipals of Depok City during flood events, and the pattern of government-citizens social media interaction during flooding, 5 February 2018. This study is an empirical study where new data collection was involved, such as: Twitter conversation scraping and interviews. From this study it was found that social media in this case Twitter is very popular as an emergency communication channel in Depok both from the citizens and government agencies. Even though the level of implementation has not been very sophisticated, Depok City Government has used social media to assist them in generating fast responses during and after flooding.
\end{abstract}

Keywords: social media, emergency, flood, government responses.

\section{Introduction}

One of technological advances that affect people's communication is the existence of social media [1]. In the field of government public relations, social media offers transparency and speed of information flow that could enforce the intensity of communication's interaction between government and citizens [2]. Through social media government agencies are able to communicate directly and effectively with citizens and vice versa [3]. Ideally, this online social media government communication is established to create double loops communication [4], exchange of ideas and information between government and citizens without going through editing process or media framing by gate keepers in conventional mainstream media [5]. This communication framework arguably allows governments to react more responsively toward citizens' demands in terms of time and accuracy.

This research is taken place in Depok City, particularly during flooding on $5^{\text {th }}$ February 2019. Why Depok City? There are several reasons. First, Depok City Government has several official social media accounts, so that it is relevant if examined in relation to the concept of government social media adoption. Secondly, Depok City is not a disaster-prone city. But part of cities that every rainy season is always faced with urban flood problems. So-called urban floods because they are not flash floods or floods that are categorized as natural disasters, but rather are quite high inundation of water, which are unable to flow or be absorbed. In Depok City, there are quite a lot of flood-prone areas. Of course this flood leaves an impact that disturbs citizens, such as the dumping of garbage, the inundated housings, and even it can exacerbate the 
problems that typically occur in cities such as traffic congestion. Third, internet users in Depok City are quite large. Based on a survey in 2013, internet users in Depok City amounted to 502,000 .

On Monday, February 5, 2018, enormous floods hit Depok City. The high intensity of the rain on that day made Kali Ciliwung overflow and inundate some parts of Depok City. Areas that are waterlogged are Kelurahan Kemirimuka, Citayam, Tirtajaya, and Pondok Cina, however, the worst conditions occur in Kemirimuka.

Research on social media use in government is very rife in this last decade, but still very few who dedicate their research to see how social media is utilized to generate actual government responses. Most initiators in this regard prefer to review the government online responses [6], [7], [8]. There are several studies that try to study about actual government responses towards social media [9], [10] but they provide little information about government policy process that transforms social media data become actual government responses. Bekkers et al. [11] became one of researchers that have initiated to describe the transformation process of social media data into actual government responses through a process known as social media monitoring.

This study will focus on crisis context in trying to explain how the process of utilizing social media can help government agencies to generate their actual crisis responses that are not only in the form of online responses. Some research has been a pioneer in this case, such as [12] [17]. Flooding in Indonesia, as a specific crisis context in this study is also a fairly new, where the majority of research related to disaster in Indonesia focuses on earthquakes and tsunami [14], [18].

This study is aiming to construct theoretical explanation about the utilization of social media by citizens and municipals of Depok City during flooding, 5 February 2018. In order to achieve the aim, there are several research questions proposed, as follows:

1. What are the manifestations of government - citizens' social media interaction can be identified during Depok City urban flooding?

2. How does Depok City Government implement social media during flood events?

3. How does Depok City Government generate quick responses during flood events?

4. How can we conceptualize the pattern among citizens' social media activities, Depok City Governments' social media Implementation, and Depok City Government Fast Responds strategy during and immediately after floods?

\section{Research Method}

This study is an empirical study where new data collection was involved, such as: interviews, observations and relevant document collection. There are 10 people who have been interviewed. Most of them are officials or employees related to the Information management particularly on social media in the technical services relating to flood management and its impacts, such Public Work Service, Health Service, Social Service, and Fire Department. The other informants are officials and employees from the Communication and Information Service, officials and volunteers at the PMI Depok City, and managers of a local social media based media. 
Another method is Twitter conversation scraping, which was scoped in the period 3-15 February 2018. The scrapped data is then classified according to 15 categories manually. This category is also not exclusive to one another. Category overlap is possible, because one text data is possible to be classified into 2 or more categories, such as tweets that indicate about complaints together with asking for help.

In downloading this twitter data, there are 2 major ways. First, by using general keywords as listed in rows 1-3. Second, data is downloaded based on the twitter account owned by the agency or unit owned by the Depok city government which is functionally related to information management and flood disaster management, as stated in rows 4-12. This difference in methods of scrapping allows overlap, where there can be the same text tweeter that appears on 2 or more methods.

Table 1. Topics Classification

\begin{tabular}{|c|c|c|c|c|c|c|c|c|c|c|c|c|c|c|}
\hline \multirow[t]{2}{*}{$\mathrm{ti}$} & \multirow[t]{2}{*}{ Scrapping Methods } & \multirow[t]{2}{*}{ Results } & \multicolumn{12}{|c|}{ Topics* } \\
\hline & & & 1 & 2 & 3 & 4 & 5 & 6 & 7 & 8 & 9 & 10 & 11 & 12 \\
\hline 1. & \#banjirdepok & 2 & 2 & - & - & - & - & - & - & 1 & - & - & - & - \\
\hline 2. & \#depokbanjir & 5 & 4 & - & - & - & 1 & 1 & - & 2 & - & - & - & - \\
\hline 3. & Banjir depok OR dpk & 342 & 313 & 21 & 17 & 6 & 69 & 6 & 3 & 126 & - & - & 11 & 2 \\
\hline 4. & (a)pemkotdepok & 762 & 43 & 17 & 7 & 11 & 7 & - & - & 4 & 2 & 5 & 14 & 1 \\
\hline 5. & From: Pemkotdepok & 91 & 9 & - & - & - & - & - & - & - & 6 & - & 2 & 1 \\
\hline 6. & To: Pemkotdepok & 94 & 7 & - & - & 6 & - & - & - & - & 1 & - & - & - \\
\hline 7. & From: Satgas_SDA & 58 & 56 & - & - & - & - & - & - & - & - & - & 56 & - \\
\hline 8. & To: Satgas_SDA & 4 & 3 & 2 & & 1 & - & - & - & - & - & - & - & - \\
\hline 9. & (a)satgas_SDA & 20 & 16 & 1 & 1 & 1 & - & - & - & - & 3 & 1 & 7 & - \\
\hline 10. & $\begin{array}{l}\text { To: } \\
\text { Depokdiskominfo }\end{array}$ & 4 & - & - & - & - & - & - & - & - & - & - & - & - \\
\hline 11. & (a) depokdiskominfo & 39 & 9 & 1 & - & - & - & - & - & - & - & - & 8 & - \\
\hline 12. & $\begin{array}{l}\text { From: } \\
\text { depokdiskominfo }\end{array}$ & 7 & - & - & - & - & - & - & - & - & - & - & - & - \\
\hline & Total & 1428 & 462 & 42 & 25 & 25 & 77 & 7 & 3 & 133 & 12 & 6 & 98 & 4 \\
\hline
\end{tabular}

\section{*Topics Classification}

1. Topics and Area relevance

2. Citizens complaint, by personal account

3. Citizens suggestion, by personal account

4. Asking for help, by personal account

5. Current situation report, by personal account

6. Idea and suggestions, by non personal and non-governmental account

7. Asking for help, by non personal and non-governmental account

8. Current situation report, by non personal and non-governmental account

9. Government response, by governmental accounts

10. Government response, by personal government officers account

11. News or reports on government response, by governmental accounts, personal government officers account, news media, or NGOs

12. Updated information about the crisis, by governmental account. 


\section{Results and Discussion}

The adoption of social media in the government communication of Depok city has been going on for quite long time. This is a manifestation of applying Law No. 14 of 2008 about Public Information Disclosure, as well as Depok City Regulation No. 3 of 2013 about the Implementation of Communication and Information Technology.

The popularity of various accounts that are officially managed by Depok City government has increased. For Twitter, per 14 May 2019, it has reached 44,650 followers. One of strategies to increase social media engagement is by linking social media account to other communication channel. Various social media links are displayed on the main page of official government website.

Twitter's popularity is manifested in flood-related virtual interactions as seen in Table 1 . The posts are dominated by reports related to the latest conditions both by the media, and the Citizens. Citizens use Twitter to report disaster situations around them or are being monitored by them. This kind of activities aims to increase awareness of disasters both for citizens and government. Citizens are found doing tagging or mentioning their tweets to some government agencies, People also use Twitter to complain about what they feel as a result of floods, and ask for help. One of the problems that often haunt society when floods occur is the accumulation of waste.

[From citizen],"@satgas_SDA SDA admin, please help with the disposal of garbage that has accumulated after the flood in Juanda, Depok, Gotong Royong hallway ",,@satgas_SDA

The benefit of adopting social media is very well recognized by Depok City government officials. The Secretary of the Communication and Information Service revealed that in the current era of information disclosure, government organizations are important to use social media as means of communication with their people. The city government can effectively publish various information and activities to the public. Regarding emergency conditions, the city government also built various communication channels such as the SIGAP application, hotline 112 specifically for emergency situations, and 119 more specifically for emergency services related to health and the need for ambulances. On the other hand social media was not given the burden of a role as important as the previous channels. It still plays as medium of dissemination of information and publication of various government activities not as a main channel of emergency communication.

In general context, the government is basically very serious about making social media as an integrated official communication channel with citizens. This is evidenced by the formation of PPID officials (information and data management officers) who are attached to all technical departments / services in Depok city government. One of its tasks particularly is managing social media. Social media admin positions are not jobs that are specifically carried out by a group of staff, but only one of obligations among many other that must be done in parallel. The presence of appointing special task force to handle social media is an indication of structural adaptation as an important indicator of social media implementation [19]. In this case, structural adaptation have been carried out by the government even though have not specifically aiming to handle social media. The lack of focus and work specification on social media admin makes the exploration of the benefits of social media become limited. The testimonies of some admins describes that they often feel that managing social media are often neglected because they have 
to work on other duties as well. Moreover, most of the admins limit themselves in managing social media only in working hours, where ironically, the disaster does not recognize working hours.

All administrators only rely on incoming notifications if there are people or other elements mentioned or sending direct messages to these official government accounts. Social media monitoring that is more holistic and advanced activity is still too sophisticated to work on. The lack of technical exploration is caused by the technology infrastructure used is just an ordinary smartphone or a regular desktop computer. In short, the process of implementing social media in Depok is not much different from the implementation of social media by individual. The only difference is the representation of the account that represents government institution not personal.

Related to generating crisis response, Rahmat as Field Coordinator of SDA Task Force and admin@satgas_SDA revealed that social media is used as a tool for preliminary assessment to assess the level of urgency of the citizens' reports/complaints to be followed up. The photo and video features of social media make it easier for people to describe and convince about the actual situation. Moreover, from the government side, photos or videos uploaded by citizens can be used as a way to avoid false information. Government of Depok City is also often seen responding to community posts by asking questions of verification and clarification.

As another form of informational response to citizens, it is also often found replies to citizens' posts in the form of virtual coordination. Admin adopt the term "cc" in the email by mentioning the accounts owned by other related units even mayor's personal account or other high officials, such as the @DinsosD account (owned by the social service department of Depok City), @DinasPUPR (public works department of Depok City), @satgas_SDA (owned by water resource department of Depok City), @manto_dpk (personal account owned by the head of public works department of Depok City) and @iidrisAShomad (privately owned by Mayor of Depok City ). The Admin also use of the phrase "your report is forwarded to ... to be followed up". This gives the impression of two things, namely whether social media is indeed a channel for virtual coordination or, that was only satisfying informational responses to citizens where the units actually coordinate offline.

The Inadequate urban physical infrastructure in the city of Depok making flood disaster seemed to be a subscripted disaster, where people who are victims seemed to have been experienced in dealing with it. The victims even seem to have been able to estimate the flood cycle, when the water level will be high and when the water will recede. The victims so often unwilling to be evacuated. This makes complaints or requests for assistance to the government regarding evacuation via social media is relatively very low. The majority of citizens conversations related to Depok floods are about infrastructure, such as broken dikes, rubbish piles that clog the waterways, and hollow roads covered by stagnant water. This makes @ satgas_SDA and @dinas_PUPR accounts become the most popular government accounts when floods occur alongside the @pemkotdepok account.

The high enthusiasm of citizens in reporting the current situation when flooding occurred, especially related to infrastructure failure created a sense of information overload. It is even recognized by Public Works Service that the agency has limited resources and ability to come up with fast and effective actual responses as expected by citizens. One of the strategies to overcome this situation is by delaying the responds. Government will respond to citizens' complaint after the issues has been fixed. Photos or videos are taken as proof and then used to convince citizens that their complaints have been handled properly. 
DinasPUPR," The activity of cleaning the waste at Laya Canal, Taman Duta.. 13/02/2018@cc:@@manto_dpk@IdrisAShomad@ @pemkotdepok pic.twitter.com/fly6flbJPl"

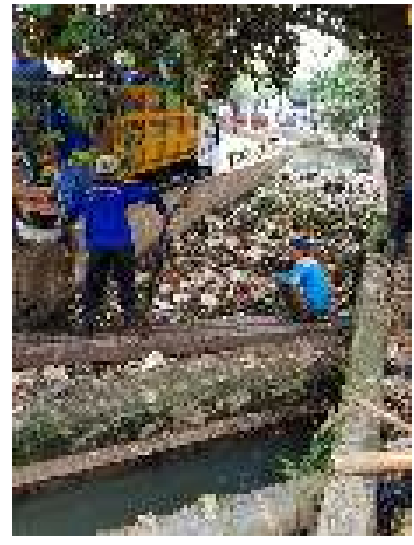

Fig. 1. Depok Government Post about Their Respons

\section{Conclusion}

The Depok City Government is one example of a city government that has made social media as one of the official communication channels between government and citizens, sometimes even as a medium of communication among internal government agencies. This process is indicated by several social media implementation strategies implemented by Depok City government, such as: ownership of social media accounts by each agency, even to sub-division levels; assigning staff specifically to handle social media; providing support for technology infrastructure, and human capacity development for social media managers and other impacted stakeholders, and also implementing response strategies.

Because social media integration is not yet optimal, especially its integration to emergency communication, the benefits of social media that are often offered in various researches are still often doubted. In some sectors, Depok city governments still prioritize the use of their field volunteers in obtaining information. Their social media implementations are not in a same level for each unit. This then makes social media less useful because the main source of information is not from the community, but still in structural way, for instance from assigned volunteers. That is why, this study found that leadership and competitiveness were the dominant factors that triggered Depok City Government to adopt social media. Unit leaders who are active on social media will encourage the optimization of the application of social media. The feeling of competing with other units or cross-city government also encourages the application of social media in Depok city.

Although social media is not considered as the official information channel regarding emergency and disaster, in this study it was found that Depok City Government was able to take advantage of social media, specifically the speed of information exchange. Depok City Government is able to take advantage of the popularity of social media, especially Twitter in 
citizens to get the latest situational information from the public to generate responses that are claimed to be faster and accurate. Maybe this idea sounds very dreamy, but the proof is present even though not in a sophisticated level of implementation. The features offered by social media help the rapid response team in conducting preliminary assessments.

Based on Depok case evidence, a theoretical notion could be propose where the effectiveness of the government's response to flooding is arguably could be impacted by social media adoption. But on the other hand, because the flooding problem in Depok City is a subscription problem faced during the rainy season annually, government's rapid or emergency responses have not been able to completely reduce the disappointment of citizens who are often ventured on social media.

Social media utilization by Depok City Government and all the service agencies leads us to the fact that there is an overlap between the impact of social media usage, and the main antecedent of government responsiveness, it is faster information exchange. Citizens participation in informing the government of their preferences in terms of their actual observations on current situation, complaints, asking for helps and even suggestions is well facilitated by social media and may even affect government performance if the government has an advanced level of social media adoption so as to respond quickly and accurately. This continuous process of communication as shown in this case, creates intimacy, mutual trust and greater collaboration between government and citizens while these also play as important element of government responsiveness.

\section{Acknowledgements.}

1. This study is part of a series of studies in several different cities that have flooding problems and the enthusiasm of using social media that are comparable to Depok, such as Bandung, South Tangerang, and Palembang. Not only that, there were also several flood cases in each city, but on this occasion only one flood case was raised.

2. Citizens personal Twitter ID is hidden.

3. Twitter posts are displayed in English.

\section{References}

[1] Bala.K.: Social media and changing communication patterns. Glob. Media J. Indian Ed.Vol. 5. pp. 1-6 (2014)

[2] Graham and Avery. E. : Government public relations and social media: An analysis of the perceptions and trends of social media use at the local government level. Public Relat. J.Vol. 7.pp. 1-21 (2013)

[3] D. Linders, "From e-government to we-government: Defining a typology for citizen coproduction in the age of social media," Gov. Inf. Q., vol. 29. pp. 446-454 (2012)

[4] C. G. Reddick, A. T. Chatfield, and A. Ojo, "A social media text analytics framework for double-loop learning for citizen-centric public services: A case study of a local government Facebook use. Government Information Quarterly, vol. 34. pp. 110-125 (2017)

[5] Boynton G. R. and G. W. Richardson Jr., "Agenda setting in the twenty-first century," New Media Soc., vol. 18.pp. 1916-1934 (2016)

[6] Al Ali, S. I. Al-Harthi, Y. AlHinai, Z. Al-Salti, and A. Al-Badi.: Citizens' perceptions of government's participatory use of social media, Transform. Gov, vol.11.pp. 174-194 (2017)

[7] R. Gauld, A. Gray, and S. McComb.: How responsive is E-Government Evidence from Australia and New Zealand," From Implement. to Adopt. Challenges to Success. E-government Diffus., vol. 26.pp. 69-74 (2009)

[8] K. N. Andersen, R. Medaglia, R. Vatrapu, H. Z. Henriksen, and R. Gauld, "The forgotten promise of e-government maturity: Assessing responsiveness in the digital public sector," Gov. Inf. Q., vol. 28, no. 4, pp. 439-445 (2011) 
[9] Eom. S.-J., H. Hwang, and J. H. Kim.: Can social media increase government responsiveness? A case study of Seoul, Korea," Gov. Inf. $Q$.

[10] P. Panagiotopoulos, J. Barnett, and L. Brooks, "Social media and government responsiveness: The case of the UK food standards agency. Lecture Notes in Computer Science (including subseries Lecture Notes in Artificial Intelligence and Lecture Notes in Bioinformatics); 12th IFIP WG 8.5 International Conference on Electronic Government, Vol. 8074. pp. 310-321 (2013)

[11] V. Bekkers, A. Edwards, and D. de Kool, "Social media monitoring: Responsive governance in the shadow of surveillance?," Gov. Inf. Q., Vol. 30. pp. 335-342 (2013)

[12] M. Song, J. W. Kim, Y. Kim, and K. Jung, "Does the provision of emergency information on social media facilitate citizen participation during a disaster. Int. J. Emerg. Manag., Vol. 11.pp. 224-239 (2015)

[13] M. T. Riccardi.: The power of crowdsourcing in disaster response operations," Int. J. Disaster Risk Reduct., Vol. 20. pp. 123-128 (2016)

[14] A. T. Chatfield, H. J. Scholl, and U. Brajawidagda, "Tsunami early warnings via Twitter in government: Net-savvy citizens' co-production of time-critical public information services," Gov. Inf. Q., vol. 30. pp. 377-386 (2013)

[15] R. Bossu.: LastQuake From rapid information to global seismic risk reduction. Int. J. Disaster Risk Reduct., Vol. 28. pp. 32-42 (2018)

[16] Yates D. and S. Paquette.: Emergency knowledge management and social media technologies: A case study of the 2010 Haitian earthquake. Int. J. Inf. Manage. Vol. 31.. pp. 6-13 (2011)

[17] Chatfield A. T. and U. Brajawidagda.: Crowdsourcing hazardous weather reports from citizens via twittersphere under the short warning lead times of EF5 intensity tornado conditions," in Proceedings of the Annual Hawaii International Conference on System Sciences; 47th Hawaii International Conference on System Sciences. HICSS. pp. 2231-2241 (2014)

[18] Comfort F. Ai, L. K., Y. Dong, and T. Znati.: A dynamic decision support system based on geographical information and mobile social networks: A model for tsunami risk mitigation in Padang, Indonesia Saf. Sci., Vol. 90, pp. 62-74 (2016)

[19] Mergel I. and S. I. Bretschneider.: A three-stage adoption process for social media use in government,Public Adm. Rev., Vol. 73. pp. 390-400 (2013) 